Proceedings

\title{
Food Spectrum of Cultivated Mussel Mytilus galloprovincialis Lam. in Suspended Culture (Black Sea, Sevastopol) ${ }^{\dagger}$
}

\author{
Natalia Pospelova * and Anastasia Priimak
}

Citation: Pospelova, N.; Priimak, A. Food Spectrum of Cultivated Mussel Mytilus galloprovincialis Lam. in Suspended Culture (Black Sea, Sevastopol). Proceedings 2021, 68, x. https://doi.org/10.3390/xxxxx

Publisher's Note: MDPI stays neutral with regard to jurisdictional claims in published maps and institutional affiliations.

Copyright: (c) 2021 by the authors. Submitted for possible open access publication under the terms and conditions of the Creative Commons Attribution (CC BY) license (http://creativecommons.org/licenses/by/4.0/).

\author{
A.O. Kovalevsky Institute of Biology of the Southern Seas of RAS, 299011 Sevastopol, Crimea; \\ 123klimova321@gmail.com \\ * Correspondence: nvpospelova@mail.ru; Tel.: +7-978-811-67-51 \\ + Presented at the 1st International Electronic Conference on Biological Diversity, Ecology and Evolution, 15- \\ 31 March 2021.
}

\begin{abstract}
In many countries molluscs are one of the main products of aquaculture. Microalgae are the most trophically valuable part of suspended organic matter in terms of filter feeders nutrition. The aim of this work is to investigate the nutritional spectrum of cultivated mussel Mytilus galloprovincialis at the Sevastopol sea-farm (Black Sea). To reach this goal the samples of sea water (1.5 litres) were thickened by reverse filtration to identify quantitative and qualitative compound of microalgae in native and concentrated sample. Molluscs were divided to different size groups. Their stomachs were prosected after sampling immediately and aliquot $0.02 \mu \mathrm{l}$ was analyzed. Quantitative and qualitative compound of microalgae in water and stomachs was defined using light microscopy. This paper provides results of comparative analysis of quantitative and qualitative microalgae compound at the Sevastopol sea-farm water and stomachs of mussel Mytilus galloprovincialis cultivating at this farm. It is showed that species composition and amount of phytoplankton in water is typical for Crimean coastal waters. The similarity in microalgae compound between water samples and mussel stomachs reached maximum in Febriary (72\%) and did not exceed $42 \%$ at the spring and autumn. Diatoms (27 species) and Dinophyta (11 species) occurred in the mussel food bolus frequently. Food spectrum of bivalves is quite wide but selectivity in filter feeders consumption is confirmed too.
\end{abstract}

Keywords: sea-farming; phytoplankton; Mytilus galloprovincialis; food spectrum; stomach content

\section{Introduction}

In many countries molluscs are one of the main products of aquaculture. Microalgae are the most trophically valuable part of suspended organic matter in terms of filter feeders nutrition. The efficiency of farming directly depends on inflow of microalgae to the farm-water. It is established that growth rate and gonad maturation of mussels is more intensive with microalgae feeding then with detritus feeding [1]. It is generally known that nutritional value of different microalgae species in terms of bivalve nutrition is unequal but this issue is not investigated completely. The knowing of M. galloprovincialis food spectrum is very important for understanding the growth rates and dynamics of its natural and artificial populations. The aim of this work is to investigate the food spectrum of cultivated mussel Mytilus galloprovincialis at the Sevastopol sea-farm (Black Sea).

\section{Experiments}

Investigations were carried out from Febriary till October 2020 at the mussel farm located in the outer roadstead of Sevastopol. Samples were taken once at two months. Samples of water (1.5 litres) were taken from the upper water layer and thickened by reverse filtration through the nuclear membranes (pore diameter $=1 \mu \mathrm{m}$ ). The microalgae content of in native and concentrated sample $(\mathrm{V}=0.01 \mathrm{ml})$ and chamber $(\mathrm{V}=0.7 \mathrm{ml})$ was 
defined by direct microscopy. Samples were processed thrice using light microscope «Jenaval» Zeiss at $10 \times 25$ magnification. Identification of taxonomic groups and species composition of microalgae was implemented using guide books [2-6].

To analyze bivalve diet their stomachs were prosected after sampling immediately and stomach content was analysed using microscope. Research was carried out for molluscs more than $4 \mathrm{~cm}$ lenght. Stomach content of 5-7 mussels of each size group was unified and sample volume was measured. Aliquot $0.02 \mu \mathrm{L}$ was taken thrice for microscoping. Microalgae species composition of water and stomachs was compared with the SørensenChekanovsky index.

\section{Results}

The range of phytoplankton cells amount in water was $25-480$ cells/L with maximum in Febriary. Total values of phytoplankton biomass varied from 95 to $166 \mu \mathrm{g} / \mathrm{L}$ and reached maximum in August against the background of dominating large-cell forms of algae. Utilizing available data and results of present paper, 10 the most frequently occurred species of microalgae are listed: 9 of them are planktonic diatoms and 1-Haptophyta E. huxleyi. The most prevailing spiceis were not always more numerous.

46 species of microalgae were identified in the stomachs, 27 of them - diatoms, 11Dinophyta, 2-Haptophyta, 2-Silicoflagellata, 2-Ebridia, 2-Chlorophyta. Microalgae number in stomachs reached maximum in Febriary due to diatoms Pseudo-nitzschia spp., S. costatum and coccolithophorida E. huxleyi. The second peak (twice smaller than first) was recorded in June due to Dinophyta Prorocentrum balticum, P. micans and coccolithophorida E. huxleyi.

The similarity in microalgae compound between water samples and mussel stomachs reached maximum in Febriary (72\%) and did not exceed $42 \%$ at the spring and autumn. The main part of stomach content belongs to dinoflagellates genus Prorocentrum- $85 \%$ of the total cell density. Only in Febriary mussel stomachs were filled with diatoms (more than $80 \%$ ) and E. huxleyi. (4-18\%).

\section{Discussion}

The composition of microalgae species in stomachs differs from that in the water. It is noticed that the number of species and cell density of bentic diatoms in stomachs is greater than in the water. It is known that mussels can collect microalgae from shells by feet [8]. Dinoflagellates were the secondary component in water and reached averagely $25-30 \%$ of the microalgae number in the stomachs. An increased amount of dinoflagellates in stomachs in comparison with phytoplankton is typical for the various bivalve species [7,9-11]. The other researches concerned with the diet of $M$. galloprovincails showed that the number of diatoms and dinoflagellates in stomachs was lower than another groups of phytoplankton [12]. It seems to be linked with the selectivity of molluscs nutrition. The results of this work and our earlier researches $[7,13]$ showed that dinoflagellates in stomachs are mainly represented by algae of the genus Prorocentrum even if in sea-water these species were few. Such selectivity can be explained by the ability of bivalves to accumulate dinoflagellates. Some authors accociate it with the short-term algae bloom of dinoflagellates that does not coincide with the time of water sampling [14,15]. It is possible that these algae species are more resistant to extracellular digestion and stay in the intestines longer [9].

While amount of plankton is crucial for mussel growth, the composition of plankton is important too. For example, microalgae that produce toxins can influence the quality of molluscs and it have to be detected as fast as possible. At the present work 2 species of toxic dinoflagellates were detected-Dinophysis acuminata and D. caudata, but the cells of these algae were sporadic both in stomachs and in water.

\section{Conclusions}


A great variety of microalgaes can be consumed by bivalves during nutrition process. That is why bivalves are the important part of a marine trophic chains. The selectivity in consumption of microalgae by cultured mussels is confirmed. However, the mechanisms of this process are not fully understood. Since growth and reproduction of bivalves depends on quality of the diet, the increase of sea-farm efficiency requires such conditions that provide availability of food for maximal generative and somatic growth of cultivated bivalves.

Author Contributions: Pospelova N. conceived and designed the experimental work; Pospelova N. and Priymak A. analyzed the data and wrote the paper.

\section{Institutional Review Board Statement:}

\section{Informed Consent Statement:}

Data Availability Statement:

Acknowledgments: The study was carried out due to the financial support of the RFBR and the Government of Sevastopol № 20-44-925001, and also RAS research grant № AAAA-A18118021350003-6).

Conflicts of Interest: the authors declare no conflict of interest.

\section{References}

1. Ivanov, V.; Kholodov, V.; Senicheva, M.; Pirkova, A.; Bulatov, K. Biology of Cultured Mussels; Naukova dumka: Kiev, Ukraine, 1989; $100 \mathrm{p}$.

2. Kiselev, I. Keys to the Fauna of the USSR. Armored Flagellates (Dinoflagellata) of the Seas and Fresh Waters of the USSR; AS USSR publishing: Moscow, Russia, 1950; $280 \mathrm{p}$.

3. Proshkina-Lavrenko, A. Diatoms of the Black Sea plankton; AS USSR publishing: Leningrad, Russia, 1955; $224 \mathrm{p}$.

4. Proshkina-Lavrenko, A. Diatoms of the Black Sea plankton; AS USSR publishing: Leningrad, Russia, 1963; 244 p.

5. Tomas, C. Marine Phytoplankton. A Guide to Naked Flagellates and Coccolithophorids. In 1. Marine Flagellates and 2. Modern Coccolithophorids; Throndsen, J., Heimdal, B.; Eds.; Academic Press: UK, 1993; 263 p.

6. Krakhmal'nyi, A. Dinophytic Algae of Ukraine (Illustrated Guide); Al'tpres: Kyiv, Ukraine, 2011; 444 p.

7. Ryabushko, L.I.; Pospelova, N.V.; Balycheva, D.S.; Kovrigina, N.P.; Troshchenko, O.A.; Kapranov, S.V. Investigations of the microphytobenthos of the Mytilus galloprovincialis Lam. Epizoon, phytoplankton and hydrological and hydrochemical characteristics of the aquatic area of the mussel farm (Sevastopol, Black Sea). Mar. Biol. J. 2017, 2, 67-83, doi:10.21072/mbj.2017.02.4.07.

8. Tsikhon-Lukanina, E. Trophology of Aquatic Molluscs; Nauka: Moscow, Russia, 1987; 177 p.

9. Rouillon, G.; Guerra Rivas, J;; Ochoa, N.; Navarro, E. Phytoplankton composition of the stomach contents of the mussel Mytilus edulis L. from two populations: comparison with its food supply. J. Shellfish. Res. 2005, 24, 5-14.

10. Senicheva, M.I. Characterization of phytoplankton as a food object for Mytilus galloprovincialis Lam. in the area of the marine economy of the Laspi Bay. Sea Ecol. 1990, 36, 7-15.

11. Xu, Q.; Yang, H. Food sources of three bivalves living in two habitats of Jiaozhou Bay (Qingdao, China): Indicated by lipid biomarkers and stable isotope analysis. J. Shellfish. Res. 2007, 26, 1-7, doi:10.2983/0730-8000(2007)26[561:FSOTBL]2.0.CO;2.

12. Prato, E.; Danieli, A.; Maffia, M.; Biandolino, F. Lipid and fatty acid compositions of Mytilus galloprovincialis cultured in the Mar Grande of Taranto (Southern Italy): feeding strategies and trophic relationships. Zool. Stud. 2010, 49, 211-219.

13. Pospelova, N.V.; Troshchenko, O.A.; Subbotin, A.A. Variability of the food supply of bivalve molluscs in a two-year cultivation cycle on a mussel farm (Black Sea, Blue Bay). Sci. Notes of V.I. Vernadsky Crime. Fed. Univ. Biology. Chem. 2018, 4, 148-164.

14. Shumway, S.; Cucci, T.; Newell, R.; Yentsch, C. Particle selection, ingestion, and absorption in filter-feeding bivalves. J. Exp. Mar. Biol. Ecol. 1985, 91, 77-92, doi:10.1016/0022-0981(85)90222-9.

15. Sidari, I.; Nichetto, P.; Cok, S.; Sosa, S.; Tubaro, A.; Honsell, G.; Della Loggia, R. Phytoplankton selection by mussel, and diarrhetic shellfish poisoning. Mar. Biol. 1998, 131, 103-111. 